\title{
Turning waste to wealth-biodegradable plastics polyhydroxyalkanoates from palm oil mill effluent - a Malaysian perspective
}

\begin{abstract}
Palm oil industries have been contributing significantly towards the countryô economy and increase standard of living among Malaysians. However, it has also been identified as the major contributor for discharging the largest pollution load throughout the country. Owing to high biochemical oxygen demand (BOD) and chemical oxygen demand (COD), the palm oil mill effluent (POME) cannot be discharged directly into the environment. Thus, palm oil industries are facing tremendous challenges in order to comply with environmental regulations. While anaerobic digestion has been employed by most mills as primary treatment, POME can also be a potential source of degradable organic material which can be converted into value-added products and fine chemicals. Organic acids generated during acidphase anaerobic digestion of POME could be a potential carbon source for the production of polyhydroxyalkanoates (PHA)- a biodegradable thermoplastic material of microbial origin. This paper aims at understanding how organic acids from POME may serve as a renewable feedstock for the biosynthesis of PHA.
\end{abstract}

Keyword: Bioconversion; Comamonas sp. EB 172; Mixed organic acids; Palm oil mill effluent; Polyhydroxyalkanoates 